\title{
PENEGAKAN HUKUM TERHADAP TIDAK NETRALNYA APARATUR SIPIL NEGARA DALAM PEMILIHAN WALIKOTA DAN WAKIL WALIKOTA CIREBON TAHUN 2018
}

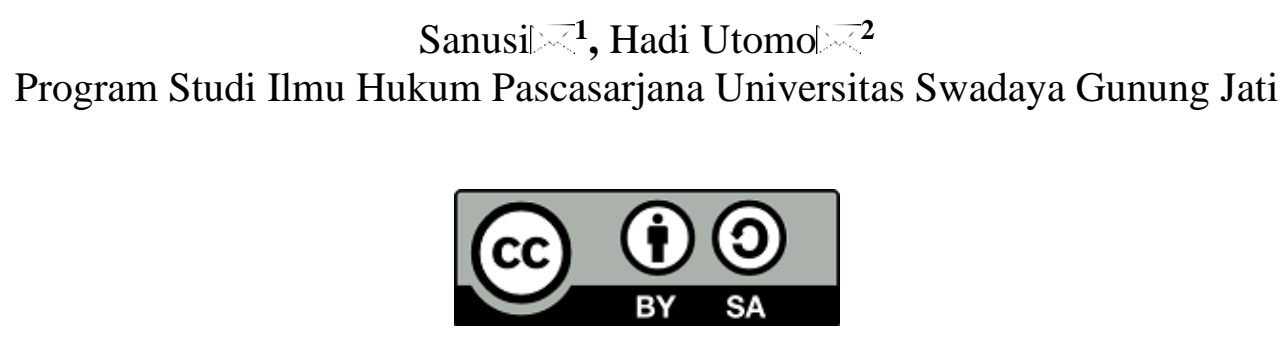

DOI: http://dx.doi.org/10.33603/hermeneutika.v3i2

Diterima: 29 November 2019; Direvisi: 16 Januari 2019; Dipublikasikan: Februari 2020

\begin{abstract}
Abstrak: Aparatur Sipil Negara (ASN) dalam Pemilihan Kepala Daerah tentunya diharuskan bersikap netral tidak boleh memihak salah satu pasangan calon, walaupun diketahui bahwa ASN juga mempunyai hak politik yaitu hak untuk memilih. Dalam prakteknya masih juga ditemui adanya keberpihakan ASN dalam Pemilihan Walikota dan Wakil Walikota Cirebon 2018. Keberpihakan ASN ini, ada yang secara tertutup ada juga yang secara terang-terangan atau terbuka. Mendukung pasangan calon secara terbuka tidak diperbolehkan dan sudah melanggar aturan. Pelanggaran tersebut harus diberikan sanksi sebagai penegakan hukum dalam pemilihan kepala daerah. Bagaimana Ketidaknetralan Aparatur Sipil Negeri (ASN) pada Pemilihan Walikota dan Wakil Walikota Cirebon tahun 2018 dan Bagaimana penegakkan Hukum kepada ASN yang tidak netral dalam Pemilihan Walikota dan Wakil Walikota Cirebon tahun 2018 menjadi permasalahan. Sedangkan Metode penelitian yang digunakan metode penelitian kualitatif untuk mendapatkan fakta mengenai permasalahan netralitas ASN di Pemilihan Walikota dan Wakil Walikota Cirebon Tahun 2018. Teknik pengumpulan data dengan cara wawancara pada instansi terkait, yaitu Panwaslu dan BKD Kota Cirebon dalam pendekatan empiris atau sosiologis. Hasil penelitian memperlihatkan ketidaknetralan ASN yang secara terbuka menyatakan dukungannya kepada paslon dengan mengunggah dukungannya di medsos sehingga dilaporkan ke Panwaslu. Panwaslu merekomendasikan ke BKPPD untuk memberikan Sanksi. BKPPD memberikan sanksi sesuai dengan UU Nomor 5 Tahun 2014 tentang Aparatur Sipil Negara.
\end{abstract}

Kata kunci: Aparatur Sipil Negeri (ASN), Netralitas, Penegakan Hukum.

\footnotetext{
${ }^{1}$ Sanusi

Email: husnulyashaq.hk@gmail.com

${ }^{2}$ Hadi Utomo $1 \cdots$

Email: hadiutomo@unswagati.ac.id
} 


\section{PENDAHULUAN}

Pelaksanaan pilkada serentak 2018 di Indonesia, dilaksanakan di 171 daerah yang tersebar 17 Provinsi, 39 kota dan 115 kabupaten. $^{3}$ Selanjutnya seluruh rakyat Indonesia berhak memilih pemimpin daerah masing-masing secara langsung sesuai dengan keinginan hati masingmasing atau sendiri, termasuk diantaranya adalah Aparatur Sipil Negara (ASN). ASN walaupun pun mempunyai hak pilih namun mereka tidak diperbolehkan mendukung atau memihak salah satu pasangan calon secara terbuka, sehingga cenderung menjadi bentuk "kampanye yang sifatnya menegaskan dukungan kepada salah satu pasangan calon".

Apalagi kadang kala ASN mudah terbawa arus politik atau dengan kata lain dalam keadaan terpaksa untuk memihak kepada salah satu pasangan calon ketika salah satu kandidat merupakan calon petahana (incumbent) ketidak netralan Aparatur Sipil Negeri juga sangat terlihat ketika ada calon kepala daerah berasal dari kalangan keluarganya sehingga nilai-nilai yang terkandung dalam azas pemilihan diabaikan, tidak mengherankan jika banyak proses politik dalam pilkada diciderai dengan adanya ASN yang mendukung salah satu paslon kepala daerah.

$\begin{array}{llr}\text { Netralitas } & \text { ASN pada } & \text { saat } \\ \text { penyelenggaraan } & \text { pilkada } & \text { sangat } \\ \text { dibutuhkan oleh } & \text { masyarakat } & \text { agar }\end{array}$
pelaksanaan pemerintahan dapat berjalan secara efektif dalam melayani masyarakat secara adil dan merata beradasarkan Undang-Undang nomor 5 tahun 2014 tentang Aparatur Sipil Negeri menyatakan salah satu asas penyelenggaran kebijakan dan manajemen adalah "netralitas", netralitas berarti bahwa setiap pegawai ASN tidak berpihak dari segala bentuk

${ }^{3}$ News.detik.com/berita/d.3479819/ini-171-daerah-yanggelarpilkada-serentak 27 koran online (diaksed pada tanggal 14 Januari 2019 pukul 17:13 wib)

${ }^{4}$ Pasal 2 huruf f Undang-Undang nomor 5 tahun 2014 tentang Aparatur Sipil pengaruh manapun dan tidak memihak kepada kepentingan siapapun.

Selain itu dalam peraturan pemerintah Nomor 53 Tahun 2010 tentang Disiplin Pegawai Negeri Sipil pasal 4 angka 14 dimana setiap PNS dilarang memberikan dukungan disertai fotokopi KTP atau surat tanda penduduk dan pasal 4 angka (15) menyatakan:

"Dengan memberikan dukungan kepada calon kepala daerah dan wakil kepala daerah dengan cara (a) terlibat dalam kegiatan kampanye; (b) menggunakan fasilitas terkait dengan jabatan terkait dengan jabatan; (c) membuat keputusan dan atau tindakan yang menguntungkan atau merugikan salah satu paslon selama masa kampanye; (d) mengadakan kegiatan atau tindakan yang mengarah kepada keberpihakan terhadap pasangan calon yang menjadi peserta pemilu sebelum,selama,dan sesudah masa kampanye meliputi pertemuan, ajakan, himbauan, seruan, pemberian barang, kepada PNS dalam lingkungan unit kerjanya anggota keluarga dan masyarakat."

Ketentuan tentang dilarangnya atau tidak dibolehkannya pegawai ASN untuk ikut serta secara langsung pada pelaksanaan pilkada juga diatur dalam Peraturan Pemerintah Nomor 42 Tahun 2004 tentang Pembinaan Jiwa dan Korps Kode Etik PNS pasal 11 Huruf c yang berbunyi:

"Dalam hal etika terhadap diri sendiri PNS wajib menghindari kepentingan pribadi, kelompok maupun golongan maka PNS dilarang melakukan perbuatan yang mengarah pada keberpihakan salah satu calon atau perbuatan yang mengindikasikan terlibat dalam politik praktis atau berafiliasi dengan partai politik misalnya (a) pendekatan kepada parpol terkait rencana pengusulan; (b) memasang spanduk atau baliho yang 
mempromosikan dirinya atau orang lain; (c) mendeklarasikan dirinya sebagai balon; (d) menghadiri deklarasi; (e) mengunggah, menanggapi, like, komentar, share $\mathrm{dsb}$ atau menyebarluaskan gambar atau foto-foto balon atau paslon melalui media online atau media social; (f) berfoto bersama balon atau paslon dengan symbol keberpihakan; (g) sebagai pembicara atau narasumber pada kegiatan partai politik".

Pelarangan keterlibatan PNS juga telah dikuatkan dengan SE Menpan RB No.B/2355/M.PANRB/07/2015 tentang Netralitas ASN dan Larangan Penggunaan Aset Pemerintah dalam Pemilihan Kepala Daerah Serentak. Larangan tersebut bukanlah dengan maksud membatasi hak asasi manusia dari ASN, namun hal ini adalah upaya menjaga PNS dari pengaruh partai politik dan untuk menjamin persatuan ASN, sehingga memusatkan perhatian, pikiran dan tenaga pada tugas yang diberikan sebagai pelayan masyarakat. ${ }^{5}$

Dengan berbagai aturan telah dibuat oleh pemerintah untuk membatasi hubungan ASN dengan kegiatan politik praktik, namun setiap berlangsungnya pelaksanan pilkada selalu diwarnai oleh maraknya pemberitaan tentang pelaksanaan netralitas oleh oknum ASN secara sembunyi-sembunyi maupun terang-terangan ikut langsung dalam proses pilkada, dan persoalan netralitas ASN tersebut seperti tidak pernah terselesaikan. ${ }^{6}$

Dalam pelaksanaan Pilkada di Bantul, Panwaslu Bantul menemukan adanya 15 ASN yang tidak netral, baik terjadi sebelum masuk masa kampanye dan selama masa kampanye. Bentuk pelanggaran tersebut adalah menghadiri

\footnotetext{
${ }^{5}$ http://aceh.tribunnews.com/2018/06/27/netralitas-pnsasn-dipilkada

${ }^{6}$ Mulya Karsona,2016,Menyoal Makna Netralitas Pegawai Aparatur Sipil Negeri
}

deklarasi dukungan PDIP yang mengusung, $\mathrm{Hj}$. Sri Surya Widati dan Misbakhul Munir sebagai calon Bupati dan Wakil Bupati di Lapangan Trirenggo, acara syukuran SP3 Drs. HM. Idham Samawi di Kantor DPC PDIP; Assek III yang menghadiri acara wayang di Pleret dan menyampaikan latar belakang calon Wakil Bupati; acara panen raya yang menghadiri calon incumbent $\mathrm{Hj}$. Sri Surya Widati dan Kepala Dinas Pertanian dan Kehutanan Bantul melakukan acara ceremonial potong padi di Bulak Balakan. ${ }^{7}$

Demikian juga yang terjadi di Pemilihan Walikota dan Wakil Walikota Cirebon Tahun 2018, banyak ASN yang berpolitik terutama mereka yang masih saudara dengan pasangan calon ataupun yang memanfaatkan untuk menduduki suatu jabatan, namun kebanyakan mereka tidak secara terang-terangan dan hanya satu yang secara terang terang atau terbuka menyatakan dukungannya kepada pasangan calon, sehingga ada yang melaporkan ke Panwaslu dan oleh Panwaslu kota Cirebon dilakukan penegakan hukum pemilihan.

\section{METODE PENELITIAN}

\section{Jenis Penelitian}

Jenis penelitian ini adalah yuridis empiris, suatu penelitian yang dilakukan terhadap keadaan sebenarnya atau keadaan nyata yang terjadi di masyarakat dengan maksud untuk mengetahui dan menemukan fakta-fakta dan data yang dibutuhkan, setelah data yang dibutuhkan terkumpul kemudian menuju identifikasi masalah yang pada akhirnya menuju pada penyelesaian masalah. ${ }^{8}$ Dikatakan yuridis empiris karena hendak mengetahui penegakan hukum terhadap ASN yang tidak netral dalam pelaksanaan pemilihan Walikota

\footnotetext{
${ }^{7}$ Widuri Wulandari, Netralitas Aparatur Sipil Negara (ASN) Dalam Pemilihan Umum Kepala Daerah Serentak Kabupaten Bantul Tahun 2015. hlm. 9

${ }^{8}$ Bambang Waluyo, Penelitian Hukum Dalam Praktek, Jakarta, Sinar Grafika, 2002, hlm.15
} 
dan Wakil Walikota Cirebon Tahun 2018.

\section{Pendekatan Penelitian}

Pendekatan yang dilakukan
dengan menggunakan yuridis
sosiologis, adalah mengindentifikasikan
dan mengkonsepsikan hukum sebagai
institusi social yang riil dan fungsional
dalam system kehidupan yang nyata.9
Pendekatan perundang-undangan
(statute approach) dilakukan dengan
menelaah semua regulasi dan peraturan
perundang-undangan yang bersangkut
paut dengan isu hukum yang akan
diteliti. Yaitu penelitian terhadap
aturan-aturan yang melarang ASN
berpolitik praktis dalam pelaksanaan
pemilihan Walikota dan Wakil
Walikota Cirebon Tahun 2018.

\section{Jenis dan Sumber Data}

Sumber data yang digunakan dalam penelitian ini diambil dari data primer, data sekunder dan data tersier.

a. Data primer adalah data yang diperoleh secara langsung dari sumber pertama yang terkait dengan permasalahan yang akan di bahas.

b. Data sekunder adalah data yang diperoleh dari pustaka atau bukubuku sebagai data pelengkap sumber data primer. Data yang diperoleh dengan melakukan kajian pustaka, berupa buku-buku, karya ilmiah, hasil penelitian dan lain lain.

c. Data tersier adalah bahan yang memberikan informasi, penjelasan terhadap bahan hukum primer dan sekunder yaitu, kamus, surat kabar, internet dan informasi lainnya yang mendukung penelitian.

\section{Teknik Pengumpulan dan Pengolahan Data}

Teknik pengumpulan data yang digunakan adalah:

a. Studi pustaka dilakukan untuk mengumpulkan data sekunder, dengan cara mempelajari peraturan perundang-undangan dan literature

${ }^{9}$ Soerjono Soekanto, Pengantar Penelitian Hukum, Jakarta, Universitas Indonesia Press, 1986, hlm. 51 lain yang berkaitan dengan penelitian.

b. Wawancara atau interview: melakukan wawancara secara langsung dalam pengumpulan fakta sosial sebagai bahan kajian ilmu hukum empiris, tanya-jawab mengenai permasalahan yang akan dibahas kepada pihak yang berwenang seperti Panitia Pengawas Pemilu (Panwaslu), Badan Kepegawaian Pendidikan dan Pelatihan Daerah (BKPPD) Kota Cirebon.

Pengolahan data merupakan bagian yang amat penting dalam metode ilmiah, karena dengan pengolahan data, data tersebut dapat diberi arti dan makna yang berguna dalam memecahkan masalah penelitian. Pengolahan data dilakukan dengan cara:

a. Pemeriksaan data (editing), yaitu melakukan pemeriksaan data yang terkumpul, sudah lengkap, sudah benar dan sesuai dengan permasalahan yang akan diteliti.

b. Klasifikasi data, dilakukan dengan cara mengelompokan data sesuai dengan pokok bahasan agar memudahkan dalam menganalisis, sesuai dengan aturan yang telah ditetapkan dalam permasalahan sehingga diperoleh data yang sebenar-benarnya.

c. Sistematisasi data, dilakukan dengan cara menyusun dan menempatkan data pada tiap-tiap pokok bahasan dengan melihat jenis serta hubungannya yang sesuai dengan permasalahan yang diteliti.

5. Pengolahan dan Analisis Data

\section{HASIL PENELITIAN}

a. Ketidaknetralan Aparatur Sipil Negara (ASN) dalam Pemilihan Walikota dan Wakil Walikota Cirebon Tahun 2018.

Bersikap netral dalam pesta demokrasi Pilkada, keharusan bagi 
aparatur sipil Negara. tentu saja tidak ditunjukkan semata pada pejabat yang berencana mencalonkan diri kembali atau incumbent/petahana. Satu hal yang harus dipahami bahwa seorang ASN harus mampu menempatkan diri sebagai abdi Negara dalam pelayanan publik yang profesional dan berkualitas, bukan melayani kepentingan pribadi, kelompok atau calon tertentu. ASN yang bekerja di birokrasi seharusnya lebih ditempatkan sebagai penjaga peraturan pemain yang disepakati lewat proses demokrasi seharusnya bersifat netral, bersih dan profesional.

Netralitas bagi ASN dalam Pilkada untuk menjaga prinsip-prinsip penyelenggaraan birokrasi yang baik, ASN sebagai penyelenggara kebijakan publik memiliki hak suara, namun pelaksanaan hak suara tersebut hanya dapat dilaksanakan melalui bilik suara dalam menggunakan hak pilihnya. Tidak boleh memihak atau mendukung salah satu pasangan calon.

Netralitas ASN pada pemilihan Walikota dan Wakil Walikota di Cirebon Tahun 2018. Hampir seluruh ASN yang ada di Kota Cirebon dianggap netral, walapun dalam kenyataannya mereka mendukung salah satu calon akan tetapi tidak ditunjukan secara terang-terangan, karena mereka sudah tahu dan mengerti aturan yang sudah ada mengenai larangan ASN beserta sanksinya.

Aparatur Sipil Negara yang
tidak secara terang-terangan
mendukung pasangan calon sebetulnya banyak juga, yang memainkan peranan penting dalam mensukseskan pasangan calonnya karena ingin menduduki satu jabatan ataupun karena merasa disingkirkan dari jabatan yang basah atau dengan istilah lain barisan sakit hati, namun karena mereka tahu dan mengerti sanksi yang akan didapat jika ketahuan secara terang-terangan mendukung salah satu pasangan calon mereka sembunyi-sembunyi.

Dengan hanya ada dua pasangan calon yang maju menjadi kontestan yaitu: Pasangan Calon Nomor urut 1 (satu) yakni $\mathrm{H}$. Bamunas Setiawan - Effendi Edo serta Pasangan Nomor Urut 2 (Dua) Drs.H.Nazarudin Azis, SH -Hj. Etty Herawati. Pasangan Calon Nomor Urut 2 merupakan Incumbent atau petahana. Sebetulnya menjadikan birokrasi yang ada di Kota Cirebon terbelah menjadi dua, ada yang mendukung dan memilih Pasangan Calon Nomor 1 serta ada yang mendukung dan memilih Pasangan Calon Nomor Urut 2.

Dukungan ASN ini, ada yang dilakukan secara sembunyi-sembunyi, namun ternyata ada juga yang secara terang-terangan mendukung salah satu pasangan calon melalui media sosial. Adanya dukungan pada pasangan calon tersebut terbukti dengan adanya laporan kepada Panwaslu Kota Cirebon. Dimana terlapor terbukti dengan sengaja mendukung pasangan calon nomor urut 1. H.Bamunas Setiawan - Effendi Edo. ASN tersebut adalah Imam Nurseto Husodo dari Badan Perencanaan Pembangunan Penelitian dan Pengembangan Daerah (BP4D).

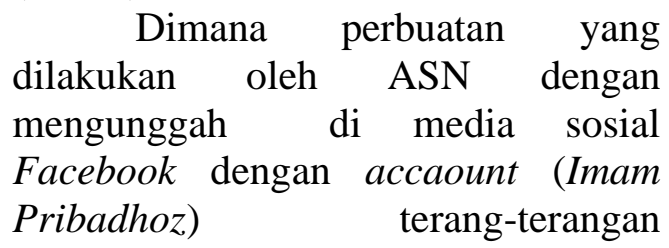
mendukung salah satu pasangan calon tersebut telah melanggar UU No. 10 Tahun 2016 Tentang perubahan kedua atas Undang-undang Nomor 1 Tahun 2015 Tentang Penetapan Peraturan Pemerintah Pengganti Undang-undang Nomor 1 Tahun 2014 Tentang Pemilihan Gubernur, Bupati dan 
Walikota menjadi Undang-undang Pasal 70 AYAT (1) huruf b, yang menyatakan bahwa :

"(1) Dalam kampanye, pasangan calon dilarang melibatkan:

b. Aparatur Sipil Negara, anggota kepolisian Negara Republik Indonesia dan anggota Tentara Nasional Indonesia; dan

Selain itu, berdasarkan Pasal 2 huruf f Undang-Undang Nomor 5 Tahun 2014 tentang ASN, bahwa:

"setiap pegawai ASN tidak berpihak dari segala pengaruh manapun dan tidak memihak kepada kepentingan siapapun.

Selain itu dalam Peraturan Pemerintah (PP) Nomor 53 Tahun 2010 tentang Disiplin Pegawai Negeri Sipil Pasal 4 angka 14 menyatakan bahwa:

"setiap PNS dilarang memberikan dukungan disertai fotokopi KTP atau surat tanda penduduk"

Dan Pasal 4 angka (15) menyatakan: "dengan memberikan dukungan kepada calon kepala daerah dan wakil kepala daerah dengan cara (a) terlibat dalam kegiatan kampanye(b) menggunakan fasilitas terkait dengan jabatan terkait dengan jabatan (c) membuat keputusan dan atau tindakan yang menguntungkan atau merugikan salah satu paslon selama masa kampanye (d) mengadakan kegiatan atau tindakan yang mengarah kepada keberpihakan terhadap pasangan calon yang menjadi peserta pemilu sebelum, selama, dan sesudah masa kampanye meliputi pertemuan, ajakan, himbauan, seruan, pemberian barang, kepada PNS dalam lingkungan unit kerjanya anggota keluarga dan masyarakat”.

Ketentuan tentang dilarangnya atau tidak dibolehkannya pegawai ASN untuk ikut serta secara langsung pada pelaksanaan pilkada juga diatur dalam Peraturan Pemerintah Nomor 42 Tahun 2004 tentang Pembinaan Jiwa dan Korps Kode Etik PNS pasal 11 Huruf c yang berbunyi:

"dalam hal etika terhadap diri sendiri PNS wajib menghindari kepentingan pribadi, kelompok maupun golongan maka PNS dilarang melakukan perbuatan yang mengarah pada keberpihakan salah satu calon atau perbuatan yang mengindikasikan terlibat dalam politik praktis atau berafiliasi dengan partai politik misalnya (a) pendekatan kepada parpol terkait rencana pengusulan (b) memasang spanduk atau baliho yang mempromosikan dirinya atau orang lain (c) mendeklarasikan dirinya sebagai balon (d) menghadiri deklarasi (e) mengunggah, menanggapi, like, komentar, share dsb atau menyebarluaskan gambar atau foto-foto balon atau paslon melalui media online atau media social $(f)$ berfoto bersama balon atau paslon dengan simbol keberpihakan $(g)$ sebagai pembicara atau narasumber pada kegiatan partai politik".

Berdasarkan aturan yang disebutkan di atas, maka Panwaslu Kota Cirebon memproses laporan yang diterima Panwaslu sesuai dengan mekanisme atau prosedur yang ada; yaitu dengan memanggil yang bersangkutan (Imam Nurseto Husodo) untuk dilakukan klarifikasi apakah benar yang bersangkutan telah mengunggah dukungan terhadap pasangan calon Nomor Urut 1 . H.Bamunas Setiawan - Effendi Edo di media sosial dan apa alasannya, di samping itu juga memperlihatkan buktinya.

Ternyata setelah diklarifikasi menyatakan bahwa ASN tersebut memang menggunggah dukungannya, namun tidak

6 Hermeneutika: Jurnal Ilmu Hukum Vol. 4, No. 1, Februari 2020 
mengetahui akan adanya larangan tidak boleh memihak dan mendukung pasangan calon. Dengan adanya klarifikasi tersebut maka Panwaslu Kota Cirebon dalam rapat plenonya memutuskan bahwa yang bersangkutan dinyatakan bersalah.

30 huruf (e) yang berbunyi "meneruskan temuan dan laporan yang bukan menjadi kewenangannya kepada instansi yang berwenang".

Yaitu memberikan dukungan kepada Pasangan Calon Walikota dan Wakil Walikota Nomor Urut 1. H.Bamunas Setiawan - Effendi Edo melalui media sosial (medsos)

1. Dan PeraturanPemerintah Nomor 53 Tahun 2004 Tentang Disiplin

Pegawai Negeri Sipil:

1. Pasal 4 angka 14 dimana setiap PNS dilarang memberikan dukungan disertai fotokopi KTP atau surat keterangan tanda penduduk.

2. Pasal 4 angka 15 dengan memeberikan dukungan kepada calon Kepala Daerah dan Wakil Kepala Daerah dengan cara:

a. Terlibat dalam kegiatan kampanye.

b. Menggunakan fasilitas yang terkait dengan jabatan.

c. Membuat keputusan atau tindakan yang mengarah kepada keberpihakan terhdap pasangan calon yang menjadi peserta pemilu, selama masa kampanye.

d. Mengadakan kegiatan atau tindakan yang mengarah kepada keberpihakan terhadap pasangan calon yang menjadi peserta pemilu,sebelum,selama,da n sesudah masa kampanye meliputi pertemuan, ajakan, himbauan, seruan, pemberian barang kepada PNS dalam lingkungan unit kerjanya,anggota dan masyarakat.

Cirebon yang ditemukan oleh Panwaslu Kota Cirebon berdasarkan laporan masyarakat berdasarkan hasil wawancara dengan Panwaslu Kota Cirebon, bahwa dugaan ASN yang tidak netral di Lingkungan Pemerintah Kota Cirebon tercatat sebanyak 1 (satu) orang yang berdasarkan hasil laporan masyarakat. ${ }^{10}$

b. Penegakan Hukum Terhadap Ketidaknetralan ASN dalam Pemilihan Walikota dan Wakil Walikota Cirebon Tahun 2018.

Keterlibatan oknum Aparatur Sipil Negara (ASN) di Lingkungan Pemerintah Kota Cirebon dengan melanggar aturan yanga ada, dimana setiap ASN tidak boleh terlibat dalam tahapan-tahapan pelaksanaan Pemilihan Kepala Daerah (Pilkada) baik sebelum, selama dan sesudah kampanye. Dalam pelaksanaan Pemilihan Walikota dan wakil Walikota Cirebon Tahun 2018. Dengan adanya laporan kepada Panwaslu Kota Cirebon, pihak Panwaslu Kota Cirebon, selanjutnya perlu mengklarifikasi laporan tersebut. Laporan tersebut ditindak lanjuti sesuai dengan mekanisme (prosedur) yang telah diatur. ${ }^{11}$

Dimana perbuatan yang dilakukan oleh ASN tersebut telah melanggar UU No. 10 Tahun 2016 Tentang perubahan kedua atas Undang-undang Nomor 1 Tahun 2015 Tentang Penetapan Peraturan Pemerintah Pengganti Undang-undang Nomor 1 Tahun 2014 Tentang Pemilihan Gubernur, Bupati dan

${ }^{10}$ Hasil Wawancara Dengan M Joharuddin, Panwaslu Kota Cirebon.

${ }^{11}$ Wawancara dengan Dimas,Humas Panwaslu Kota Cirebon,Pads Tanggal 23 Maret 2019 
Walikota menjadi Undang-undang Pasal 30 huruf (e) yang berbunyi "meneruskan temuan dan laporan yang bukan menjadi kewenangannya kepada instansi yang berwenang".

$$
\text { Yang }
$$

berwenang memberikan sanksi adalah BKPPD 1. Penundaan jabatan selama 1 tahun dan penundaan kenaikan gaji. Sanksi berdasarkan Majelis Sidang Etik antara Inspektorat Daerah dan BKPPD (Badan Kepegawaian Pendidikan dan Pelatihan Daerah.

\section{Gambar 1: Mekanisme Penjatuhan} Sanksi sebelum adanya penetapan pasangan calon Walikota dan Wakil Walikota Cirebon.

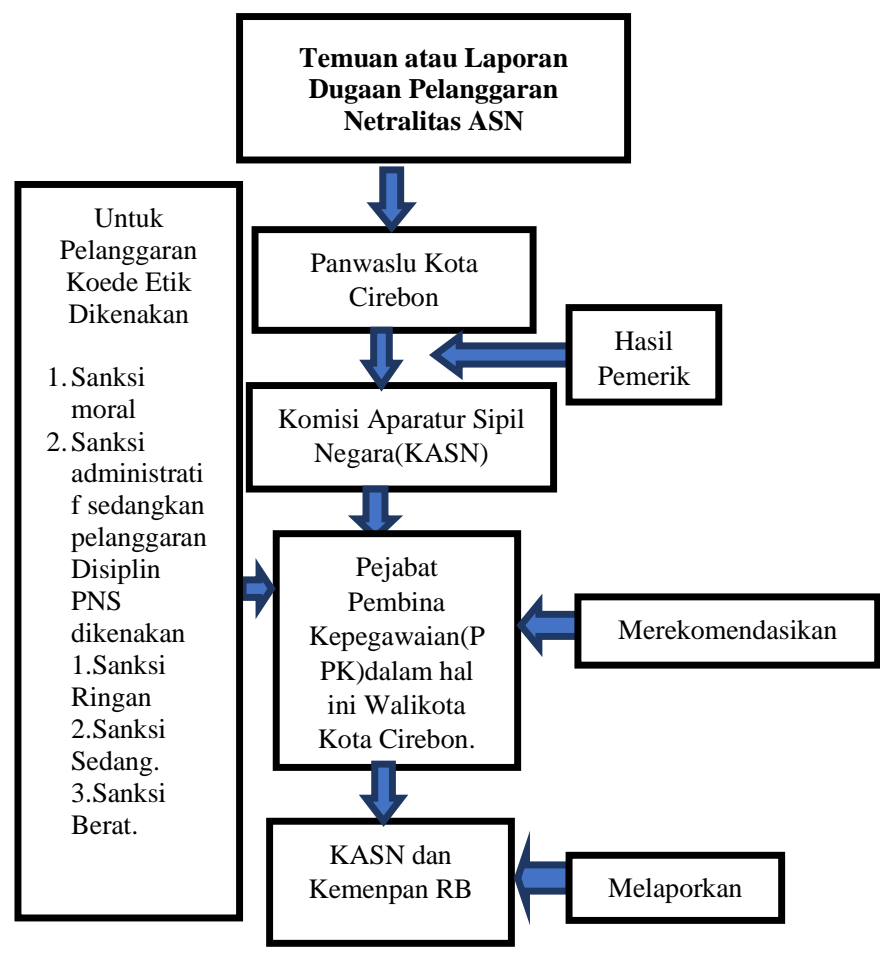

Sumber: Inspektorat Daerah Kota Cirebon
Gambar 2: Mekanisme Penjatuhan Sanksi setelah adanya penetapan pasangan calon Walikota dan Wakil Walikota Cirebon.

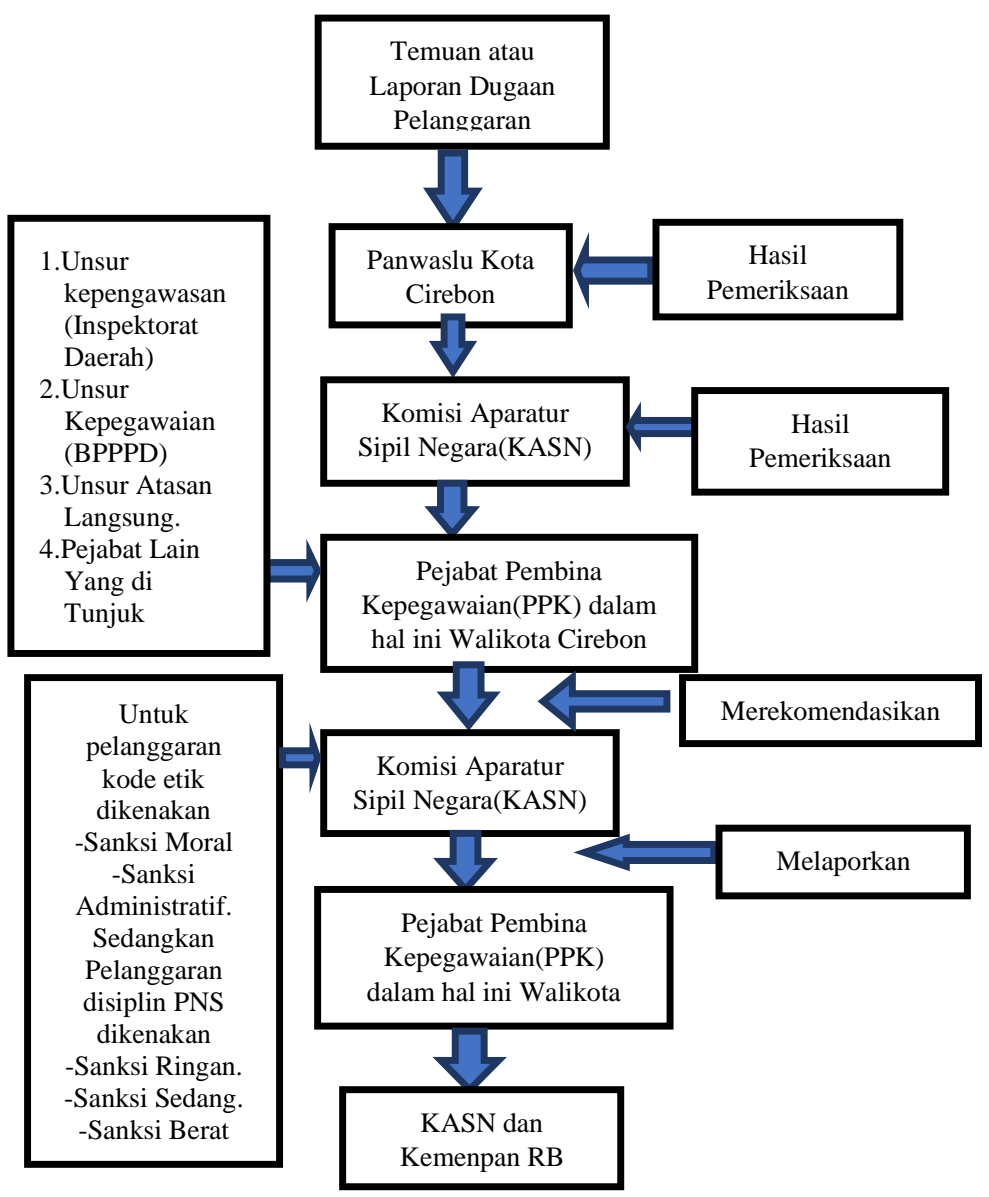

\section{Sumber: Inspektorat Daerah Kota Cirebon}

Berikut adalah penjelasan Gambar 1 dan 2 diatas,yaitu:

1. Pemanggilan.

Tahap pertama dalam proses pemeriksaan terhadap oknum ASN Pemerintah Kota Cirebon diduga tidak netral tersebut dilakukan oleh Panwaslu Kota Cirrebon dengan cara melakukan pemanggilan dilakukan 7(tujuh) hari kerja sebelum tanggal pemeriksaan.Dalam pemanggilan ini, oknum ASN pemerintah Kota Cirebon yang diduga tidak netral tersebut memenuhi syarat pada tahap pemanggilan .Tahapan yang dilakukan 
ini telah sesuai dengan Pasal 23 ayat (1)dan (2) Peraturan pemerintah Nomor 53 Tahun 2010 Tentang Disiplin Pegawai Negeri Sipil.

2. Pemeriksaan

Pada tahap pemeriksaan ini setelah adanya pemanggilan yang dilakukan oleh Panwaslu Kota Cirebon Oknum ASN yang diduga tidak Netral dalam pelaksanaan Pilkada Kota Cirebon, diperiksa oleh pihak Panwaslu Kota Cirebon yakni pemeriksaan dilakukan dengan tanya jawab untuk pembuktian jika oknum tersebut melakukan peanggaran.dalam pemeriksaan ini dilakukan secara tertutup,oknum ASN tersebut mengakui bahwa ia melakukan keberpihakan terhadap salah satu Calon Kepala daerah Kota Cirebon dengan alasan bahwa dukungan tersebut diberikan secara pribadi dan terbuka terhadap calon Walikota tersebut. ${ }^{12}$ selanjutnya dari hasil pemeriksaan dilakukan oleh pihak Panwaslu Kota Cirebon bahwa adanya kajian terhadap pelanggaran kode etik dan pelanggaran Peraturan Pemerintah Nomor 53 Tahun 2010 tentang Disiplin PNS dalam hal pelanggaran tersebut diteruskan kepada KASN dalam hal ini lembaga yang berwenang dalam menjatuhkan sanksi sesuai peraturan perundang-undangan.

Pada tahap ini terdapat perbedaan mengenai prosedur penjatuhan sanksi ASN yang tidak netral sebelum adanya penetapan calon Walikota dan Wakil Walikota dengan setelah ditetapkan calon Walikota dan Wakil Walikota $^{13}$ dimana untuk pelanggaran yang dilakukan ASN sebelum adanya penetapan pasangan Calon Walikota

\footnotetext{
${ }^{12}$ Hasil Wawancara dengan Suwarso Budi Winarno,Irban I Inspektorat Daerah Kota Cirebon.Pada Tanggal 02 Mei 2019

${ }^{13}$ Hasil Wawancara Dengan Suwarso Budi Winarno,Irban I Inspektorat Daerah Kota Cirebon.Pada Tanggal 02 Mei 2019
}

dan Wakil Walikota .Hasil pemeriksaan Panwaslu diteruskan ke Komisi Aparatur Sipil Negara untuk dijatuhi sanksi tetap mengkoordinasikan kepada Pejabat Pembina Kepegawaian dalam hal ini Walikota Cirebon dalam langkah tindak lanjut, PPK atau Walikota menindaklanjuti Rekomendasi KASN tersebut tetap diawasi langsung oleh KASN dan Kemenpan RB.

Sedangkan apabila pelanggaran dilakukan ASN setelah penetapan pasangan calon Walikota dan Wakil Walikota,yakni :

a. Hasil pemeriksaan dari Panwaslu diteruskan kepada KASN.

b. Sebelum KASN menjatuhi sanksi, dikembalikan lagi ke pejabat Pembina Kepegawain untuk memeriksa kembali dengan membentuk tim pemeriksa diantaranya:

1) Unsur pengawas atau Inspektorat Daerah

2) Unsur kepegawaian atau BPPPD

3) Unsur atasan Langsung atau SKPD PNS.

4) Pejabat lain yang ditunjuk.

c. Hasil pemeriksaan PPK tersebut ,diteruskan kepada KASN untuk menjatuhkan sanksi paling lama 14(empat belas)hari.

d. Setelah itu,PPK atau walikota menindaklanjuti rekomendasi KASN yang diawasi langsung oleh KASN dan Kemenpan RB.

Dari tahapan pemeriksan tersebut telah sesuai dengan pasal 24 ayat(2) dan 25 Peraturan Pemerintah Nomor 53 Tahun 2010 Tentang Disiplin Pegawai Negeri Sipil 
3. Penjatuhan sanksi.

Berdasarkan peraturan hukum yang berlaku, penjatuhan sanksi dilakukan oleh pejabat atau instansi yang berwenang. Adapun yang berwenang menjatuhkan sansi yaitu Komisi Aparatur Sipil Negara.yang tetap mengkoordinasikan kepada Pejabat Pembina Kepegawaian dalam hal ini Walikota Cirebon dalam langkah tindak lanjut.

Adapun sanksi yang diberikan kepada ASN tidak netral sesuai dengan tingkat pelanggaran ASN tersebut. Dimana jika ASN melakukan pelanggaran kode etik maka dikenakan sanksi moral maupun sanksi administratif, sedangkan ASN melakukan pelanggaran terkait disiplin Pegawai Negeri Sipil (PNS) maka dijatuhkan hukuman disiplin PNS, yakni:

1) Tingkat hukuman disiplin terdiri:

a. Hukuman siplin rungan.

b. Hukuman dsiplin sedang dan

c. Hukuman disiplin berat.

2) Jenis hukuman ringan sebagaimana dimaksud pada ayat(1) huruf a terdiri dari:
a. Teguran lisan.
b. Teguran tertulis dan
c. Pernyataan tidak puas secara tertulis.

3) Jenis hukuman disiplin sedang sebagaimana dimaksud pada ayat

(1) huruf $b$ terdiri dari:

a. Penundaan kenaikan gaji berkala selama 1(satu) tahun.

b. Penundaan kenaikan pangkat selama 1(satu) tahun.dan

c. Penurunan pangkat setingkat lebih rendah selama 1(satu) tahun.

4) Jenis hukuman disiplin berat sebagaimanadimaksud pada ayat(1) huruf $\mathrm{c}$ terdiri dari:

a. Penurunan pangkat setingkat lebih rendah selama 3(tiga) tahun . b. Pemindahan dalam rangka penurunan jabatan setingkat lebih rendah.

c. Pembebasan dari jabatan.

d. Pemberhentian dengan hormat tidak atas permintaab sendirisebagai PNS; dan.

e. Pemberhentian tidak dengan hormat sebagai PNS.

Rekomendasi yang ditindak lanjuti oleh Pejabat Pembina Kepegawaian adalah sebagai berikut:

1) Menjatuhkan sanksi kepada Oknum ASN pada instansi BP4D Kota Cirebon berdasarkan ketentuan peraturan perundang-undangan yang berlaku yakni perbuatan yang dilanggar/dilakukan oleh oknum ASN tersebut merupakan kedalam jenis Pelanggaran Disiplin sedang yang termaktub pada ayat 1 huruf (b) UU Nomor 5 Tahun 2014 tentang Aparatur Sipil Negara yakni dengan penjatuhan hukunan berupa: ${ }^{14}$

a. Penundaan kenaikan Gaji berkala selama 1(satu) tahun.

b. Penundaan kenaikan jabatan selama 1(satu) tahun.

\section{KESIMPULAN}

Berdasarkan hasil pembahsan diatas maka dapat disimpulkan bahwa netralitas Aparatur Sipil Negara pada pelaksanaan pemilihan Kepala Daerah di Kota Cirebon belum terlaksana dengan baik karena masih ditemukan adanya ASN yang memihak kepada salah satu Pasangan Calon secara terang-terangan atau terbuka kepada masyarakat atau publkik, walaupun tidak dipungkiri ada juga yang memihak namun tidak terangterangan dan terbuka. Bagi ASN yang secara terang-terangan memihak kepada salah satu Calon selama pelaksanaan pilkada terutama pada masa kampanye, maka akan diproses oleh Panwaslu Kota

\footnotetext{
${ }^{14}$ Hasil Wawancara Dengan Suwarso Budi Winarno, Irban I Inspektorat Daerah Kota Cirebon.Pada Tanggal 02 Mei 2019
} 
Cirebon, jika terbukti melanggar undangundang yang berlaku akan dikenakan sanksi.

Pelaksanaan penegakan Hukum mengenai ASN yang tidak Netral atau memberikan dukungan secara terangterangan oleh Panwaslu Kota Cirebon telah dilaksanakan dengan proses Pemanggilan Saksi-saksi sampai dengan memberikan rekomendasi kepada Institusi terkait dalam hal ini BKPPD dan Inspektorat Daerah Kota Cirebon sesuai prosedur dengan dilakukannya pemanggilan dan rekomendasi pada instansi yang berwenang (BKPPD). Selanjutnya rekomendasi tersebut ditindaklanjuti oleh BKPPD dengan memberikan sanksi. Sesuai dengan ayat 1 huruf (b) UU Nomor 5 Tahun 2014 tentang Aparatur Sipil Negara yakni dengan penjatuhan hukunan berupa: 1 . Penundaan kenaikan Gaji berkala selama 1 (satu) tahun. Dan Penundaan kenaikan jabatan selama 1(satu) tahun.

\section{DAFTAR PUSTAKA}

Abdullah, 2012, Hukum Kepegawaian Indonesia, Rengkang Education Indonesia

Catur Wijayanti dan Iwan Setiawan,2009, Hukum Tata Negara,Yogyakarta

Jimly Ashiddiqie, 2011, Konstitusi dan Konstitusionalisme Indonesia, Grafika

Kumolo, 2015, Politik Hukum Pilkada Serentak, Jakarta

Mulya Karsona, 2016, Menyoal Makna Netralitas Pegawai Aparatur Sipil Negeri

Ni'matul Huda.2013.Hukum Tata Negara Indonesia .Rajawali Pers Ed.Revisi.cet ke 8 Jakarta.

Ramlan Subakti .2008. Sistem Pemilu dan Tatanan Politik Demokrasi. Pustaka Pelajar.Yogyakarta.

Samsul huda,2013, Hukum Tata Negara Indonesia, Rajawali Pers, Jakarta.
Sartiptjo Rahardjo, 1995, Masalah Penegakan Hukum Suatu Tinjauan Sosiologis, Sinar Baru, Bandung,

S.F Marbun.1998. Reformasi Hukum Tata Negara, Netralitas Pegawai Negeri dalam Kehidupan Politik Di Indonesia. Yogyakarta. Fakultas Hukum Universitas Islam Indonesia. Yogyakarta.

S.F Marbun dan Mahfud M.D.PokokPokok Hukum Administrasi Negara. Liberty. Yogyakarta.

Soerjono Soekanto, 1983, Faktor-Faktor Yang Mempengaruhi Penegakan Hukum, UI Press, Jakarta.

\section{Perundang-undangan:}

Undang-undang Dasar Negara Kesatuan Republik Indonesia tahun 1945

Undang-Undang nomor 8 Tahun 2015 Tentang Perubahan Atas Penetapan Peraturan Pemerintah Pengganti Undang-Undang Nomor 23 Tahun 2004 Tentang Pemilihan Gubernur, Bupati dan Walikota Menjadi Undang-Undang.

Undang-Undang nomor 5 tahun 2014 tentang Aparatur Sipil.

Undang -Undang Nomor 10 Tahun 2016 Tentang Perubahan Kedua atas Undang-Undang Nomor 1 Tahun 2015 Tentang Penetapan Peraturan Pemerintah Pengganti UndangUndang Nomor 1 Tahun 2014 Tentang Pemilihan Gubernur,Bupati dan Walikota Menjadi UndangUndang.

Undang -Undang Nomor 15 Tahun 2011 Tentang Penyelenggara Pemilihan Umum.

Peraturan Pemerintah Nomor 42 Tahun 2004 Tentang Pembinaan jiwa dan Korps Kode Etik PNS.

Peraturan Pemerintah Nomor 53 Tahun 2010 Tentang Disiplin Pegawai Negeri. 